\title{
What is The Character of Student Tolerance in The Indonesian Political Situation?
}

\author{
Agus Supriyanto, Sri Hartini, Amien Wahyudi \\ Department of Guidance and Counseling \\ Universitas Ahmad Dahlan \\ Yogyakarta, Indonesia \\ agus.supriyanto@bk.uad.ac.id
}

\begin{abstract}
Indonesian students have a variety of cultures, languages, ethnicities, and religions. A variety of religions also influence the tolerance character in political choice of the Indonesian president. The presidential election in 2019 is a complex problem and raises cases of intolerance. The study measures the tolerance of character students as voters in the 2019 presidential election through a quantitative descriptive approach. The research subjects were 739 with the character scale tolerance instrument. The findings explained that the tolerance character of students in political conditions or presidential elections has high criteria. The peace aspect when the presidential election has high criteria, aspects respect each other the difference in choice in the low criteria and the of self-awareness aspect in the high criteria. Comfort in personal life in the low criteria and fear of students in the high criteria. Character education in schools as a solution to the tolerance character development.
\end{abstract}

Keywords-tolerance character; character building

\section{INTRODUCTION}

Indonesia has a variety of cultures, languages, ethnicities, and religions. This diversity comes from Sabang to Merauke. The diversity of cultures, languages, ethnicities, races, ethnicities, and religions in Indonesia [1] influences the educational process in building the identity and values of nationalism, harmony, character, and morality by using archipelagic thinking, local wisdom, and multiculturalism [2]. Indonesia's diversity also influences every political choice in the 2019 Presidential Election and 2017 Jakarta Governor Election. The condition that multiculturalism ignores similarities and emphasizes differences that impact conflict [3]. The difference in each in Indonesia is something special, one of them is the difference in political choice in the presidential election.

The difference in presidential choices in Indonesia is a complex problem because local identity politics that are ethnic and religious in various places in Indonesia have created open and violent conflicts [4] in the form of aggressive behavior in students. The tendency of aggressive behavior arises in the form of physical aggression, verbal aggression, anger, and hatred [5]. Aggressiveness also arises through relational and social media [6]. Aggression behavior that arises in political conditions has an impact on the tolerance character of students due to differences in political choices.
Indonesia is one of the Southeast Asian Nations (ASEAN) and one of the inevitable post-colonial countries of multiculturalism [7]. Indonesia, as a multicultural country has diverse differences and equality of goals. The same goal as a multicultural country is implemented in the form of a shared desire as the Indonesian nation at national and local levels to adopt Pancasila as its life guide, a common understanding among experts on the meaning of multiculturalism, and joint and shared efforts to realize the ideals of the Indonesian nation [8].

Multiculturalism also occurs in Indonesia's political dynamics. Political tensions in Indonesia and Malaysia over the election of national leaders influence culture and religion [9]. Religious intolerance in Indonesia, the impact of the 2014 Indonesian presidential election reflects a shift in Indonesian politics from doctrinal and philosophical issues to pragmatism [10], [11].

Multicultural education creates a generation of participatory, empowered, active, Indonesian citizens [12] through choice differences. The difference in choice is maturity for each, one of them is high school level students. Political differences teach students to practice being students with character, namely, character tolerance. Character education, one of which is the character of tolerance, is implemented formally and informally at school [13].

Character tolerance is implemented through character education. Realization of the tolerance character through the form of policies, attitudes, opinions [14]. Three aspects of tolerance character form aspects of peace, aspects of respecting differences and individuals, and aspects of consciousness [15]. Tolerance education is a solution to foster mutual recognition, mutual respect, and respect for one another [16].

Middle School Students as voters in the 2019 presidential election have the tolerance characters resulting from the implementation of character education. The tolerance character in students can be seen from the views of students as a result of the presidential election campaign through social media. The impact of the presidential election campaign is tolerance [17]. The impact of the presidential election is to ensure justice and avoid possible conflicts [18]. 
Tolerance is defined as ethical neutrality or mutual respect for differences [19]. The tolerance characters an attitude of mutual respect through understanding with the aim of peace. Tolerance is toward peace. Peace creates a peaceful mind [20].

The tolerance characters have points of reflection. The points of reflection are (a) peace is the goal; (b) tolerance is open and receptive to the beauty of difference; (c) tolerance of respect for individuals and differences; (d) tolerance is mutual respect for one another; (e) the seeds of intolerance are fear and indifference; (f) the seed of tolerance is love; $(\mathrm{g})$ if not love there is no tolerance; (h) who know appreciate goodness in others and situations have tolerance; (i) tolerance means facing difficult situations; and (j) tolerance to the discomfort of living by letting it pass, lighten, and let others [21]. These reflection points of tolerance character will deliver peace between individuals in the world. Character education becomes the main foundation in fostering the character of Indonesian nation through education.

The tolerance character is a character that is indicated by human attitudes and behavior that do not deviate from the rules, in which a person appreciates or respects every action that others do. Tolerance is called the essential factor for peace. The meaning of peace itself as an internal human condition that has a peaceful mind to itself when faced with certain situations [22].

The measurement of the tolerance character in the selector or student has never been measured. The purpose of this study was to find facts about the tolerance character of students as voters in the presidential election in 2019. Measurement of the tolerance character in students as voters becomes important and urgent. The importance of measuring the tolerance character of students to find out the character of student tolerance in three aspects (peace, respecting differences and individuals, and awareness). An assessment of the tolerance characters used in character education programs in Indonesia. Character education to help students develop good character effectively and comprehensively [23]. This discovery is to find out the character of tolerance amid differences as voters.

\section{METHOD}

This study uses a quantitative approach with a type of descriptive research. The product of the research is the discovery of the tolerance character in the conditions of the political situation. The research subjects were students as voters in the Indonesian presidential election with a total of $\mathrm{N}$ $=739$. The research subjects were high school students or vocational high schools in four districts and the city of Yogyakarta. Research location in the Special Province of Yogyakarta.

This study uses a character tolerance scale instrument that contains three aspects of student tolerance character that have been validated and are suitable for use. The tolerance character measured in the aspect of peace is an indicator of caring, fear, and love. While the aspect of respecting differences and individuals is measured about indicators of mutual respect for one another, respect for differences in others, and self-respect. Measurements about aspects of consciousness include indicators of respecting the good of others, being open, receptive, comfort in life, and comfort with others. The three aspects with all indicators are measured to determine the level of character tolerance of students as voters in the political situation and resident elections in 2019. Total items total of 39 .

Data analysis uses quantitative or descriptive quantitative approaches. Quantitative descriptive analysis carried out by researchers is useful for carrying out testing. Data analysis uses percentages and categorization. The categories from the analysis using the standard deviation (SD). The SD approach works to determine agreement limits, coefficient of variation and difference [24]. The results of the analysis are discussed and compared with the results of other studies, so finding new findings and suggestions for the development of the tolerance character in education in Indonesia.

\section{RESUlTS AND DISCUSSION}

The study was conducted on 739 students in the Special Province of Yogyakarta. The study was conducted in four districts and one city. Bantul Regency, Sleman Regency, Kulonprogo Regency, Gunungkidul Regency, and Yogyakarta City. The following are the results of research on the tolerance character of students as voters in the political situation of presidential elections in Indonesia.

\section{A. Tolerance Character}

The average character tolerance of students is $78.84 \%$ or high criteria. In more detail, $41.4 \%$ of students have high criteria, and $12.4 \%$ have very high criteria. While $43.4 \%$ have low criteria, and 3.0 percent have very low criteria. Although on average, they have high criteria, most of the students who number $43.4 \%$ have a tolerance character with low criteria.

The findings of the character of tolerance of Indonesian students are by the principles of Islamic religion, that tolerance is respect for humanity, without discriminating with each other [25]. Religious values and cultural values also form the foundation for developing tolerance [26]. The fact is that a strong traditional attitude in Indonesia also influences tolerance in students [27].

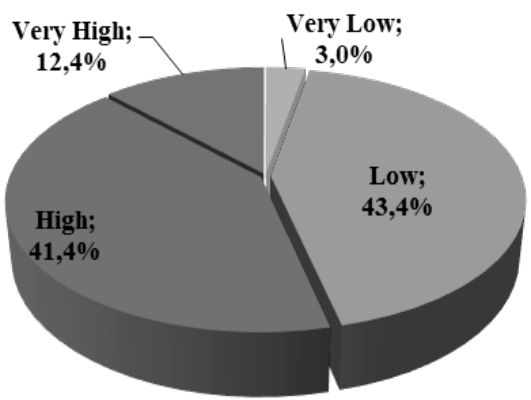

Fig. 1. Tolerance Character Of Indonesian Student 


\section{B. Peace Aspect}

One aspect of the tolerance characters' peace. The peace aspect is high, with an average of $78.87 \%$. The details are $64.8 \%$ of students have high peace, and $26.0 \%$ have very high criteria. A small percentage of students have low peace of $8.9 \%$, and $0.3 \%$ are very low. The meaning is that Indonesian students have and want peace.

Implementation of peace aspects in the tolerance character requires the role of guidance and counseling teacher. Effective guidance for students in developing an initial understanding of education through social justice attitudes and openness [28]. Peace education can manage conflicts and differences that can deepen democracy through curricula to create positive citizens [29]. Peace produces positive results in improving functional conflict resolution skills, and respect for social conventions for positive peace and youth development [30].

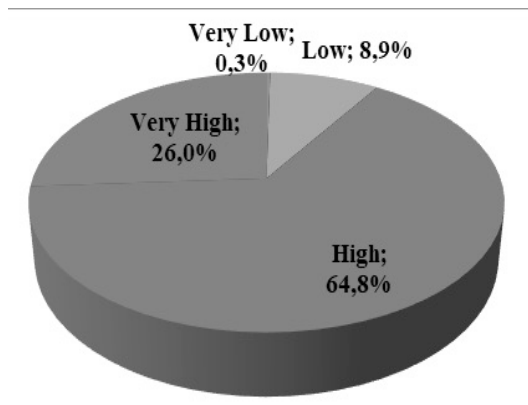

Fig. 2. Peace Aspect of Indonesian Student

\section{Mutual Respect}

Unlike the aspect of peace, the aspect of mutual respect for students is very worrying. The average aspect of mutual respect is low. Most students or $44.7 \%$ have low respect, and $7.7 \%$ have mutual respect for very low criteria. While $33.7 \%$ have high respect and $13.9 \%$ of students are on very high criteria.

A distinctive difference from the results of research becomes a problem for students. The results of the study are supported by the fact that gender and diversity attitudes are related to racist behavior [31]. The issue of differences in voting attitudes also needs the role of the teacher through character education. Character education always encourages solids and continually prepares future leaders [32].

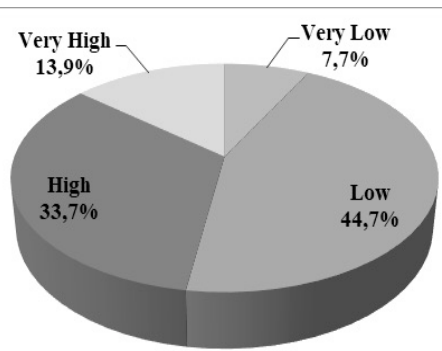

Fig. 3. The aspect of Mutually Appreciating the Differences of Indonesian Student

\section{Self Awareness Aspects}

The third aspect is self-awareness. The average selfawareness of students in the high criteria. The results show that $40.2 \%$ of students 'self-awareness in the high criteria and $12.9 \%$ of students' self-awareness in the criteria is very high. While $44.4 \%$ of students 'self-awareness in the low criteria and $2.6 \%$ of students' self-awareness in the low criteria.

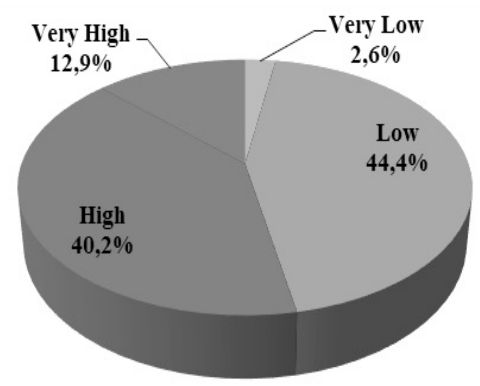

Fig. 4. Self- Awareness Aspect of Indonesian Student

\section{E. Character Tolerance Indicator}

The results of the analysis of each indicator find the latest fact that mutual respect for individuals or Indonesian students is in low criteria. More detailed is mutual respect for one another, respect for differences in others, and self-respect in the low criteria. In the aspect of peace, students have a high caring and loving attitude, but also high fear. In the aspect of self-awareness, students have high criteria of respect for the goodness of others, are open, receptive, and comfortable with others. Whereas comfort in personal life is in low criteria.

TABLE I. INDICATORS OF THE TOLERANCE CHARACTER OF INDONESIAN STUDENT

\begin{tabular}{|c|c|c|c|}
\hline No & $\begin{array}{c}\text { Points of Tolerance } \\
\text { Character }\end{array}$ & $\begin{array}{c}\text { Tolerance Character } \\
\text { Indicators }\end{array}$ & Criteria \\
\hline \multirow[t]{3}{*}{1} & \multirow[t]{3}{*}{ Peace } & Care & High \\
\hline & & Fare & High \\
\hline & & Love & High \\
\hline \multirow[t]{3}{*}{2} & \multirow{3}{*}{$\begin{array}{l}\text { Appreciating } \\
\text { Differences and } \\
\text { Individuals }\end{array}$} & Respect each other & Low \\
\hline & & $\begin{array}{l}\text { Appreciating the } \\
\text { Differences of Other }\end{array}$ & Low \\
\hline & & Respecting Yourself & Low \\
\hline \multirow[t]{5}{*}{3} & \multirow[t]{5}{*}{ Self- Awareness } & $\begin{array}{l}\text { Appreciating the Godness } \\
\text { of Others }\end{array}$ & High \\
\hline & & Open & High \\
\hline & & Receptive & High \\
\hline & & Comfort in Life & Low \\
\hline & & Comfort with Others & High \\
\hline
\end{tabular}

Character education to overcome intolerance and tolerance character development must be practiced by subject teachers or school counselor. Character education helps students develop good character including caring, respect, responsibility, honesty, fairness, and compassion. Character strength is the main basis for optimal personal development and effective life [33]. Character education to shape student character. The formation of teenage characters is a big challenge for educators and collaboration with parents [34]. 
The development of the tolerance character of students also pays attention to the current era or millennial era. Students learn about the good character through literacy learning [35].

\section{CONCLUSION}

The character of student tolerance in political conditions or presidential elections is ethical neutrality or mutual respect for differences in political choice. The tolerance character of Indonesian students in the high criteria. The character of students' tolerance as voters in the presidential election is divided into three aspects. The aspect of peace in students when the presidential election has high criteria. Aspects of mutual respect for differences in choices in students when the presidential election has low criteria. The aspect of selfawareness in students during the presidential election is in the high criteria, although comfort in personal life is in low criteria.

\section{ACKNOWLEDGMENT}

This research is fully supported by Affiliation Research Grant Beginner Lecturer Ministry of Research and Technology Dikti, Indonesia. Thank you to the Institute for Research and Community Service at Ahmad Dahlan University.

\section{REFERENCES}

[1] A. Irhandayaningsih, "Kajian Filosofis Terhadap Multikulturalisme Indonesia," Humanika, vol. 15, no. 9, Jan. 2012.

[2] C.-Y. Hoon, "Putting Religion into Multiculturalism: Conceptualising Religious Multiculturalism in Indonesia," Asian Studies Review, vol. 41, no. 3, pp. 476-493, Jul. 2017.

[3] I. Meliono, "Understanding the Nusantara thought and local wisdom as an aspect of the Indonesian education," TAWARIKH, vol. 2, no. 2, 2011.

[4] T. J. Lan, "Heterogeneity, politics of ethnicity, and multiculturalism What is a viable framework for Indonesia?" Wacana, vol. 13, no. 2, pp. 279-292, 2011.

[5] D. A. Gentile, S. Coyne, and D. A. Walsh, "Media violence, physical aggression, and relational aggression in school age children: a shortterm longitudinal study," Aggressive behavior, vol. 37, no. 2, pp. 193206, 2011.

[6] S. Alhadi, P. Purwadi, S. Muyana, W. N. E. Saputra, and A. Supriyanto, "Agresivitas Siswa SMP di Yogyakarta," Jurnal Fokus Konseling, vol. 4, no. 1, pp. 93-99-99, Jan. 2018.

[7] C. B. Huat, "Multiculturalism in Island South-East Asian," Antropologi Indonesia, 2014.

[8] P. Suparlan, "Menuju masyarakat Indonesia yang multikultural," Antropologi Indonesia, 2014.

[9] J. Pietsch and M. Clark, Indonesia-Malaysia relations: Cultural heritage, politics and labour migration. Routledge, 2014.

[10] G. Fealy, "The Politics of Religious Intolerance in Indonesia: Mainstream-ism Trumps Extremism?" in Religion, Law and Intolerance in Indonesia, Routledge, 2016, pp. 115-131.

[11] N. G. Sumaktoyo, V. Ottati, and V. Untoro, "The paradoxical religiosity effect: Religion and Politics in Indonesia and the United States," Politics and Religion, vol. 9, no. 3, pp. 481-507, 2016.

[12] C.-Y. Hoon, "Multicultural citizenship education in Indonesia: The case of a Chinese Christian school," Journal of Southeast Asian Studies, vol. 44, no. 3, pp. 490-510, 2013.

[13] M. Watz, "An historical analysis of character education," Journal of Inquiry and Action in Education, vol. 4, no. 2, p. 3, 2011.
[14] H. Marcuse, "Repressive tolerance," in Political Elites in a Democracy, Routledge, 2017, pp. 138-169.

[15] A. Supriyanto and A. Wahyudi, "Skala karakter toleransi: konsep dan operasional aspek kedamaian, menghargai perbedaan dan kesadaran individu," Counsellia: Jurnal Bimbingan dan Konseling, vol. 7, no. 2, pp. 61-70, 2017.

[16] E. Sugianto, "Pendidikan Toleransi Beragama Bagi Generasi Milenial," Misykat al-Anwar Jurnal Kajian Islam dan Masyarakat, vol. 30, no. 1, 2019.

[17] S. Paramita, "Menyoal Kampanye Politik: Dalam Film Our Brand Is Crisis," 2019.

[18] N. Prasetyoningsih, "Dampak Pemilihan Umum serentak bagi pembangunan demokrasi Indonesia," Media Hukum, vol. 21, no. 2, p. 23, 2014.

[19] J. Budziszewski, True tolerance: liberalism and the necessity of judgment. Routledge, 2017.

[20] D. Tillman, "Pendidikan Nilai Untuk Kaum Muda Dewasa (Terjemahan Risa Pratono),” Jakarta: Grasindo, 2004.

[21] A. Wahyudi, "Character Education: Literatur Study Religious Tolerance Character," in Prosiding Seminar Bimbingan dan Konseling, 2017, vol. 1, pp. 49-56.

[22] J. Galtung, "Theories of peace: A synthetic approach to peace thinking," International Peace Research Institute, Oslo, vol. 2, no. 6, 1967.

[23] A. Pala, "The need for character education," International Journal of Social Sciences and Humanity Studies, vol. 3, no. 2, pp. 23-32, 2011.

[24] A. Donner and G. Y. Zou, "Closed-form confidence intervals for functions of the normal mean and standard deviation," Statistical Methods in Medical Research, vol. 21, no. 4, pp. 347-359, 2012.

[25] A. Bakar, "Konsep toleransi dan kebebasan beragama," Toleransi, vol. 7, no. 2, pp. 123-131, 2016.

[26] L. Nisvilyah, "Toleransi Antarumat Beragama Dalam Memperkokoh Persatuan Dan Kesatuan Bangsa (Studi Kasus Umat Islam Dan Kristen Dusun Segaran Kecamatan Dlanggu Kabupaten Mojokerto)," Kajian Moral dan Kewarganegaraan, vol. 2, no. 1, pp. 382-396, 2013.

[27] D. Bustan, S. H. Sani, and N. Pariz, "Adaptive fault-tolerant spacecraft attitude control design with transient response control," IEEE/ASME Transactions on Mechatronics, vol. 19, no. 4, pp. 1404-1411, 2013.

[28] D. H. Christopher and M. J. Taylor, "Social justice and critical peace education: Common ideals guiding student teacher transformation," Journal of Peace Education, vol. 8, no. 3, pp. 295-313, 2011.

[29] K. Bickmore, "Keeping, making, and building peace in school," Social Education, vol. 75, no. 1, pp. 40-44, 2011.

[30] L. Gerstein, B. Lindsey, S. Alisha, and A. Akpan, "Implementing sport for peace principles with elementary school student leaders," Revista de Cercetare si Interventie Sociala, vol. 45, p. 7, 2014.

[31] H. A. Neville, V. P. Poteat, J. A. Lewis, and L. B. Spanierman, "Changes in White college students' color-blind racial ideology over 4 years: Do diversity experiences make a difference?" Journal of counseling psychology, vol. 61, no. 2, p. 179, 2014.

[32] A. Agboola and K. C. Tsai, "Bring character education into classroom," European journal of educational research, vol. 1, no. 2, pp. 163-170, 2012

[33] N. Park and C. Peterson, "Character strengths: Research and practice," Journal of college and character, vol. 10, no. 4, 2009.

[34] D. K. Lapsley and D. Yeager, "Moral-character education," Handbook of Psychology, Second Edition, vol. 7, 2012.

[35] G. M. Almerico, "Building Character through Literacy with Children's Literature.," Research in Higher Education Journal, vol. 26, 2014. 